\title{
I 304
} 尿中ジクロロタン分析によるジクロロメ夕ン曝露の生物学的モニタリング

○樢飼博彦: 岡本 浩 ${ }^{1}$ 高田志郎”乾修然: : 河合俊夫 ${ }^{21}$ 池田正之 （1）京都工場保健会 2)中災防大阪センター)

【目的】近年、産業現場で洗浄用溶剂等として、使用が急增しているジクロロメタン（DCM）について、作業 者の曝露濃度と尿中に排泄される D C M を測定し、尿中 D C M 分析により D C M 曝露に対する生物学的モニ夕り ングが可能か否かを検討する。

【対象と方法】洗浄作業に従事し、D C M に曝露されている作業者61名（男子46名、女子15名）と非曝露者8名 （男子 4 名、女子 4 名）を対象とした。曝露濃度の測定については、活性炭を吸着材とした払散型個人サンブラ 一を使用したが、D C M は活性炭では自然脱着が認められ、測定可能時間は大略 4 時間以内である(1997年、本学 会、演題H109）。したがって、サンプラーを午前と午後とに分けて装着してもらい、午前、午後㧍よび全日の作業時 間中の時間加重平均浱度を求めた。一方、尿中DCMの測定については、作業終了時にD C M の污染のない場所 で採尿をし、直ちにバイアル㼛に5四分取し、ヘッドスペースーE C D ーガスクロマトグラフ法により測定した。 尿比重、尿中クレアチニン濃度は常法によった。

【結果】気中 D C M (全日) の幾何平均灌度は $9.9 \mathrm{ppm、}$ 幾何摽準偏差は4.32（最高濃度180.0 ppm）であった。 午前、午後抢よび全日の気中 D C M 濃度と尿中 D C M 浱 度との間には、尿の濃淡の補正の有無にかかわらず、有 意な相関 $(p<0.01)$ が認奻られ、特に全日の場合には高い 相関を示した（図1）。尿中DCM浱度を比重抒よびク レアチニン濃度により補正しても、相関の向上は認めら れなかった。また、全日について、男女别に回㷌式の傾 きの比較により、男女のDCMの排泄速度を比較したが、 差は認められなかった（p>0.05）（表 1）。以上から、尿 中 D C M は D C M 曝露指標として有用であり、生物学的 モニタリングが可能であると考えられる。

表 1 気中 D C M 濃度と尿中 D C M 濃度の関係

\begin{tabular}{|c|c|c|c|c|}
\hline \multirow{2}{*}{ 気中濃度の区分 } & \multicolumn{4}{|c|}{ 回㷌式 ${ }^{\mathrm{a}}$ ) } \\
\hline & 切片 $(\alpha)$ & 傾き( $\beta$ ) & 相関係 & \\
\hline $\begin{array}{l}\text { 午前の場合 } \\
\text { 実測値 } \\
\text { 外チニ哺正 } \\
\text { 比重補正 }(1.016)\end{array}$ & $\begin{array}{l}10.4 \\
19.0 \\
17.8\end{array}$ & $\begin{array}{l}2.09 \\
1.44 \\
1.50\end{array}$ & $\begin{array}{l}0.811 \\
0.713 \\
0.784\end{array}$ & $\begin{array}{l}* \\
* \\
*\end{array}$ \\
\hline $\begin{array}{l}\text { 午後の場合 } \\
\text { 実測値 } \\
\text { 快チニ補正 } \\
\text { 比重補正 }(1.016) \\
\end{array}$ & $\begin{array}{r}17.3 \\
9.8 \\
11.7 \\
\end{array}$ & $\begin{array}{l}3.72 \\
2.86 \\
2.78 \\
\end{array}$ & $\begin{array}{l}0.865 \\
0.847 \\
0.870\end{array}$ & $\begin{array}{l}* \\
* \\
*\end{array}$ \\
\hline $\begin{array}{l}\text { 全日の場合 } \\
\text { 実測值 } \\
\text { 外于ニ補正 } \\
\text { 比重補正 }(1,016)\end{array}$ & $\begin{array}{l}7.7 \\
6.0 \\
5.9\end{array}$ & $\begin{array}{l}3.22 \\
2.32 \\
2.35\end{array}$ & $\begin{array}{l}0.911 \\
0.837 \\
0.895\end{array}$ & $\begin{array}{l}* \\
* \\
*\end{array}$ \\
\hline $\begin{array}{l}\text { 全日の場合（男） } \\
\text { 実測値 } \\
\text { 舛千補正 } \\
\text { 比重補正 }(1.016)\end{array}$ & $\begin{array}{l}8.8 \\
0.6 \\
3.4\end{array}$ & $\begin{array}{l}3.30 \\
2.50 \\
2.46\end{array}$ & $\begin{array}{l}0.896 \\
0.824 \\
0.882\end{array}$ & $\begin{array}{l}* \\
* \\
*\end{array}$ \\
\hline $\begin{array}{l}\text { 実測値 } \\
\text { クレアチニン補正 } \\
\text { 此重補正 }(1.016)\end{array}$ & $\begin{array}{r}3.6 \\
15.7 \\
9.9 \\
\end{array}$ & $\begin{array}{l}3.03 \\
1.94 \\
2.10\end{array}$ & $\begin{array}{l}0.958 \\
0.918 \\
0.943\end{array}$ & $\begin{array}{l}* \\
* \\
*\end{array}$ \\
\hline
\end{tabular}

a): 切片 $(\alpha)$ 、傾き $(\beta)$ は回㷌式 $Y=\alpha+\beta X$ の係数 Yは尿中 D C M 濃度 $(\mu \mathrm{g} / 1)$

$\mathrm{X}$ は気中 D C M 濃度 $(\mathrm{ppm}), * \mathrm{p}<0.01$

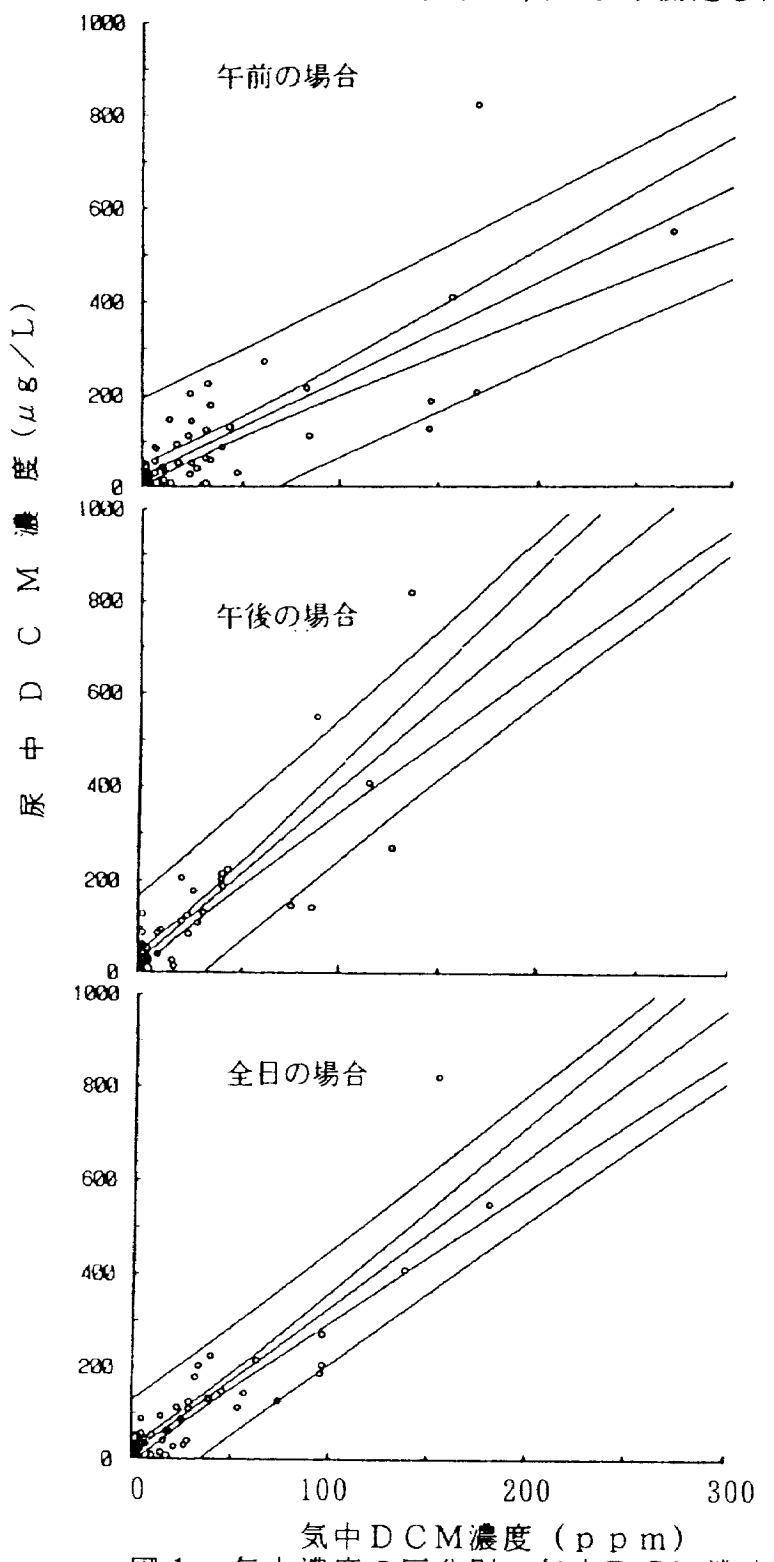

図1気中濃度の区分別の気中D C M 濃度と 尿中 D C M 濃度（実測值）上の関係 